\title{
Muddied Waters: The Case for Mitigating Sediment and Nutrient Flux to Optimize Restoration Response in the Murray-Darling Basin, Australia
}

\author{
Peter A. Gell ${ }^{1 *}$ and Michael A. Reid ${ }^{2}$ \\ ${ }^{1}$ Water Research Network, Federation University Australia, Mt Helen, VIC, Australia, ${ }^{2}$ Geography and Planning, Riverine \\ Landscapes Research Laboratory, University of New England, Armidale, NSW, Australia
}

OPEN ACCESS

Edited by:

Franco Biondi,

University of Nevada, USA

Reviewed by:

Bernhard Wehrli,

ETH Zurich, Switzerland

John Richard Dodson,

Australian Nuclear Science and

Technology Organisation, Australia

*Correspondence:

Peter A. Gell

p.gell@federation.edu.au

Specialty section:

This article was submitted to

Paleoecology,

a section of the journal

Frontiers in Ecology and Evolution

Received: 30 April 2015

Accepted: 15 February 2016

Published: 07 March 2016

Citation:

Gell PA and Reid MA (2016) Muddied

Waters: The Case for Mitigating

Sediment and Nutrient Flux to

Optimize Restoration Response in the

Murray-Darling Basin, Australia.

Front. Ecol. Evol. 4:16

doi: 10.3389/fevo.2016.00016
The waters of the Murray Darling Basin, Australia, have endured multiple stressors for more than a century. Detectable salinization impacts are evident from $1880 \mathrm{CE}$ and elevated fluxes of sediments and nutrients are now widespread. Most wetlands examined paleolimnologically have shown increased sedimentation rates or have lost aquatic plant communities due to the shading effect of increased turbidity, prompting the observation that the waterways of the Murray Darling Basin are among 10 Australian ecosystems most at risk from tipping points. This post-European heightened sediment flux threatens the potential ecological recovery from the application of scarce and expensive environmental water. Nutrients and fine sediments are implicated as drivers of regime shifts that advantage phytoplankton and inhibit the growth of productive macrophyte beds. However, with the river channels identified as likely sources of sediments and sediment-bound phosphorous, it remains possible that the documented ecological changes represent an ongoing response from continued doses from the River. Syntheses of multiple paleolimnological records provide evidence for the management focus to be on sediment supply to maximize the ecological benefit from environmental flow allocations. Here we use paleolimnology to examine in detail the nature and magnitude of the response in a subset of 17 wetlands, to propose means of optimizing the ecological bounce from the release of river waters, encumbered with high doses of sediments and nutrients, to wetlands and floodplains.

Keywords: diatoms, wetlands, floodplain, regime shift, environmental flows, sediments, turbidity

\section{INTRODUCTION}

Much research on the wetlands of the Murray Darling Basin, Australia, has taken place over recent decades using contemporary approaches of hydrology and limnology. The high level of abstraction since the 1960s has drawn focus to changes in flow and water volume as principal drivers of wetland change (Jones et al., 2002a). Also, the regulation of the system from the 1920s is regarded as a major driver of change. In concert, these forces have led to reductions in the connectivity between the river and its floodplain which change trophic dynamics, the seasonality of peak flow that alters 
breeding triggers, the temperature of releases and its impact on fecundity, and the increase in the permanency of wetlands linked to weir pools (Walker and Thoms, 1993). This broad appreciation of the impacts that were brought with twentieth century change has led to a management response dominated by water volume (Maheshwari et al., 1995). So, after more than a decade of vehement contest over water allocations to the environmental reserve, the Murray Darling Basin Plan has allocated 3200 Giga Liters (GL) of water to fulfill obligations under international treaties to the restoration of wetlands across the catchment (MDBA, 2013).

Monitoring of the waters of the Basin commenced in 1951 and this program has been augmented both in breadth and frequency as concern for the ecological condition of the system has become elevated through to the present (Norris et al., 2002; Davies et al., 2012). This research has enabled the production of report cards that have attested to the degraded state of the system and justified calls for the returns of considerable volumes of water from consumptive allocations to the environment. However, no data pre-dating regulation, or the initiation of the principal phase of water resource development (1950-1995), exists. As such, management is largely blind to the baseline ecological condition and the historical range of variability that existed before the peak period of industrialized development. It is also blind to any abrupt changes that may have occurred before regulation. For example, geomorphic evidence of severe gully erosion soon after settlement suggests catchment pressures on wetland condition may have begun as early as the mid1800s (Prosser et al., 2001). Underlying these anthropogenic drivers, there are also long term trajectories of change that originate from the nascence of wetlands. These remain elements to be considered in the management of these systems but are opaque to those whose focus is on recent changes observed using contemporary approaches.

Ongoing and widespread concerns for the welfare of the aquatic ecosystems of the Murray Darling Basin (Laurance et al., 2011), particularly in the light of the impact of a drying climate (Jones et al., 2002b; Pittock and Finlayson, 2011), have ultimately seen the release and implementation of the Murray Darling Basin Plan, amid great controversy. It is proposed that $3200 \mathrm{GL}$ of water be returned to the natural environment to improve the ecological health of the system (MDBA, 2013). Originally, this was proposed to be borne largely by water buy-backs from the irrigated agriculture industry (at an estimated cost of \$5.5 B), however more interest is now on freeing water for the environment by investing in infrastructure designed to minimize evaporative losses (at an estimated cost of \$27.5 B; Wittwer and Dixon, 2013). This represents an unprecedented investment in Australia's environmental health and a significant, potential opportunity cost to production from irrigated agriculture through reduced water allocations. There remains little means, other than short term monitoring, to ascertain the ecological benefit from the allocation of such resources. There remains considerable risk that the response from this substantial, and unusual, investment in environmental remediation will be muted, on account of the legacy of stressors poorly identified due to the prevalence of short term research (Gell and Reid, 2014). Politically, the cause for investment in ecosystem health, against that for production from irrigation agriculture, may hinge on the ecosystem science community's credibility in circumscribing the benefit from allocation of scarce and expensive water.

Regime shifts have been a long posited model to explain the shift from a macrophyte-rich state in a wetland to one dominated by phytoplankton (Scheffer et al., 1993; Scheffer and Carpenter, 2003). While Davis et al. (2010) proposed such a mechanism when explaining changes to relatively permanent wetlands in the Swan Coastal Plain (WA), a recent meta-analysis of research claiming to have demonstrated regimes shifts found few revealed a lack of recovery after the removal of the stressor and fewer still demonstrated the shifting feedbacks that would entrench a wetland in an alternate state (Capon et al., 2015). The few that were found to justifiably claim evidence for a threshold change were from shallow lakes. This is supported by widespread evidence for phytoplankton-dominated systems today in wetlands that were once productive, macrophyterich waters. The forces of landscape, hydrological and climatic change that may impact upon a wetland are diverse but are likely to have come to bear on the condition of wetlands from early in the industrialized phase, and potentially, early in the sedentarization of people (Bradshaw et al., 2005, 2006). It would be coincidental if the pressures brought by humanity all came to bear on wetlands over the last few decades after reliable monitoring technologies became available. So, it is unlikely that contemporary ecological sampling could reveal regime shifts. Given the absence of historical data, or observations of sufficient detail to show non-linear change, the demonstration of regime shifts must rely heavily on records of long term change available in paleolimnology.

Many paleolimnological studies of shallow lakes have demonstrated abrupt change. For example, Ogden (2000) observed the loss of aquatic macrophytes in large, deep Murray Darling Basin wetlands due to their vulnerability to light attenuation. Sayer et al. (2010) demonstrate gradual regime shifts in constructed wetlands in Norfolk, UK. Wang et al. (2012) revealed abrupt changes in Lake Erhai, China, which followed increasing variability in diatom assemblages in response to increased nutrient loading. Further, Davidson et al. (2013) found that, among 10 billabong sites in the northern and southern Murray Darling Basin, most experienced significant declines in the diversity of benthic diatom communities across the European settlement boundary. Similarly, Kattel et al. (2014) have documented the loss of diverse, littoral cladoceran communities coincident with the rise of phytoplankton in a lower Murray River wetland. They observed however, that it remains uncertain whether this change is due to continued, chronic dosing with river-borne sediment and phosphorus or whether it represents a regime shift reinforced by the establishment of stabilizing feedbacks that lock the wetland into a state rich in pelagic biota, but depauperate in littoral biota.

The resilience of a wetland to reductions in flow relate to its capacity to recover, and retain its identity, after wet conditions return. Intuitively, this resilience could be informed by an understanding of the historic and pre-historic changes a wetland has previously experienced. The contemporary 
hydrogeomorphic regime of the southern Murray Darling Basin was established after the mid-Holocene pluvial phase. So the broad mechanisms that control the present meander wavelength and the production rate of cutoff meanders has been in place for 7000 years. Jones et al. (1998) revealed that, through this period $\mathrm{P} / \mathrm{E}$ ratios have varied from 1.2 to 0.7 and Barr et al. (2014) have demonstrated the existence of multi-decadal droughts. Using instrumental data Warner (1987) revealed multi-decadal drought-dominated and flood-dominated regimes. So, while the focus of contemporary society is on shorter frequency, ENSO cycles and their effects, the system has experienced variations of even greater duration and amplitude in the past. Given this natural variability, wetlands and river channels might be expected to have considerably more natural resilience with respect to flow variations than the present report cards suggest. If so, it is likely that other stressors exert a strong influence on condition to the point where they have contributed to the assessment of extensive degradation.

While the impact of industrialized people on Australian ecosystems commenced early in settlement, environmental management programs continue to seek "baseline" information from surveys conducted in the late twentieth century, and even later (Marsland and Nicol, 2007). So the systems we seek to manage, based on recent monitoring were already, and often substantially, impacted, before conditions were first assessed. By these means we are unable to see our real ecological heritage, measure the magnitude of the shift from a real baseline, or attribute the cause (Reid and Ogden, 2006). Without evidence from the past we are unaware of the changes to our natural systems that occur through time (Tibby et al., 2007a,b). The identification of targets for restoration can be largely political and so the past may never be the goal for future investment. Nevertheless, ignorance of the trajectory of change denies scientists, managers and investors alike, evidence of system evolution, cause, and response.

Evidence for the evolution of a wetland is buried away, year upon year, in its sediments. It is somewhat obscured by the variable preservation of key lines of evidence, but emerging technologies are both releasing new lines of evidence, and establishing better timelines of change. Evidence of wetland condition are becoming increasingly accessible as more and more bioindicators, such as eDNA (e.g., Giguet-Covex et al., 2014), are extracted from its archive. While substantial funds are invested to monitor the contemporary condition of impacted systems over long periods of time, relatively few resources can be invested to understand natural assets lost, the magnitude of ecosystem change and the underlying causes of food web simplification.

Many wetlands of the Murray River host continuous sediment records that extend to the time they commenced accumulating sediments-probably at a point after they were lost to the scouring flows of the main channel. Others that regularly dried presumably lost their sediment due to deflation and only commenced continuous sediment accumulation after they became permanent after river regulation. So, some cutoff meanders with large wavelength morphology have records of change that span several millennia (Gell et al., 2005a; Reid et al., 2007) while others have shorter records extending back into the early twentieth century only (Gell et al., 2007). In combination, they provide an opportunity to examine the response of wetlands to many drivers-fewer to the longer term forces such as millennial scale climate variability, and many more to the impact of river regulation and catchment disturbance after European settlement. A typical record shows muted response to climate but an abrupt response to elevated sediment loads and river regulation following industrialization. Attributing these changes to a cause is somewhat limited by the difficulty of establishing a sub-decadal chronology to the sediment record due to challenges faced in the use of radiometric techniques in fluvial settings (Gell et al., 2005a). Nevertheless, it is clear that there has been widespread change in Murray Darling Basin wetlands that are likely due to a greater suite of causes than merely loss of flow and connectivity (Dearing et al., 2015).

This paper draws on existing palaeoecological records from the Murray-Darling Basin to illustrate how floodplain wetlands have been affected by catchment land use change and water resource development. These are used to demonstrate the importance of addressing stressors such as elevated nutrient and sediment fluxes in parallel with hydrological change in efforts to manage and preserve these important ecosystems. Two approaches are used in relation to the existing records: first, a general review and synthesis of the full suite of available records to explore evidence of elevated sediment fluxes and water quality change, especially in relation to nutrients; and second, a reanalysis of a subset of the records to explore patterns in relation to evidence of abrupt loss of submerged macrophytes and potential hydro-geomorphic controls over wetland resilience with respect to macrophyte loss.

\section{MATERIALS AND METHODS}

\section{Synthesis of Evidence in Billabong Sediment Records of Sediment Flux and Water Quality Change}

Over 50 sediment-based records of change, using fossil diatoms and various dating techniques, have been undertaken in Murray Darling Basin wetlands (Gell and Reid, 2014). Some of these records have been published and interpreted in detail (Gell et al., 2005a,b, 2007; Gell and Little, 2006; Reid et al., 2007; Fluin et al., 2010; Grundell et al., 2012; Kattel et al., 2014), some appear as research dissertations (Silva, 2014) and others are available in unpublished reports. Field and laboratory methods used in each of these studies are detailed in the literature cited above. In broad terms, however, sediment records at each site are derived from sediment cores taken from the deepest sections of each billabong, in most cases supported by multiple cores used to assess general stratigraphy. In addition to diatoms, most studies also include physical, chemical, and other biological indicators such as moisture and organic content, sediment texture, magnetic susceptibility, pollen, macrofossils, and pigments.

While the records in some are underpinned with a range of dating approaches such as ${ }^{14} \mathrm{C}$ AMS, ${ }^{210} \mathrm{~Pb},{ }^{137} \mathrm{Cs}$, OSL, and exotic pollen others are supported by limited dating control. 
Given the carbonate-rich nature of the landscape and high level of fluvial transport of fine sediments few records are supported by clear chronologies and so attributing changes to points in history remains challenging. Nevertheless, broad changes in sedimentation rate can be inferred and clear evidence of broad changes are evident. In many instances, these can be attributed to particular management interventions in the past, such as the establishment of a network of weirs, mostly between 1922 and 1936.

The water quality changes inferred from these records are based on the known water quality preferences of the diatoms preserved in the sediments. Samples are treated using standard techniques (Battarbee et al., 2001) and mounted on microscope slides. Species are identified using standard international (Krammer and Lange-Bertalot, 1986, 1988, 1991a,b) and local floras (Sonneman et al., 2000) usually assisted by microphotography. Taxonomic harmonization between laboratories was assisted by the staging of taxonomic workshops that were central to the production of the local floras.

While these flora formed the basis for the local interpretation of the water quality preferences of common taxa an extensive diatom biomonitoring program across south-eastern Australia, using diatoms, enabled the calibration of species to water quality parameters (Philibert et al., 2006) and the production of an index of stream degradation (Chessman et al., 2007), the Diatom Species Index of Australian Rivers (DSIAR). Ecological interpretations were also based on international indices of water quality, such as Van Dam et al. (1994), as well as the large body of diatom species-water salinity calibration data sets (e.g., Fritz et al., 1991; Gasse et al., 1995; Gell, 1997; Fritz, 1999). Given the changing nature of floodplain wetlands are influenced by the nature of the wetland, but also the river, and the variable interactions between, interpretations of fossil records were aided by insights from river channel diatom samples (Tibby and Reid, 2004) collected routinely by the basin management agency as well as through a diatom-water quality monitoring program of river-connected wetlands (Gell et al., 2002). The complex interactions between the river and its wetlands was considered to preclude the widespread use of transfer functions to quantitatively infer water quality changes although this was attempted in some instances (e.g., Tibby et al., 2003; Gell et al., 2007; Reid and Ogden, 2009). The recent synthesis (Gell and Reid, 2014) summarizes the diatom-inferred change evident in the records reporting on the temporal extent of the record and changes in sedimentation rate since European settlement. It also reports on water quality changes, such as increases in salinity and nutrients and changes in $\mathrm{pH}$, using the known water quality preferences of common diatom taxa. Evidence from these records attests to widespread increases in sedimentation rate and variable evidence for shifts from macrophyte- to phytoplanktondominance in billabongs (Figure 1). Also, they report an increase in eutraphentic taxa and a decline in those known to be competitive in low nutrients conditions on account of them hosting nitrogen fixing endosymbionts (Stancheva et al., 2013) marking a rise in nutrients loads. Importantly, the response varies between sites with some wetlands appearing resistant to change and those more sensitive changing abruptly, particularly

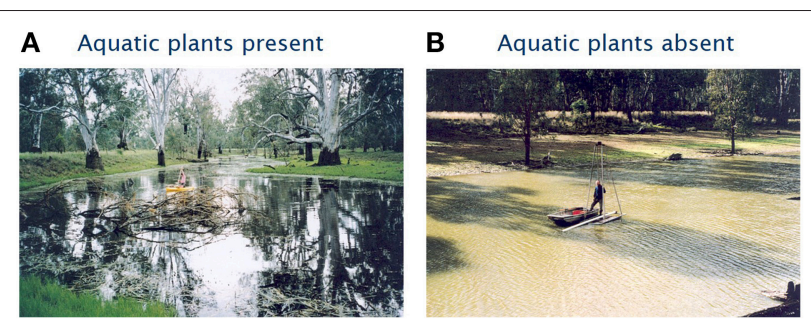

FIGURE 1 | Two billabongs from the Murray Darling Basin (A), clearwater macrophyte-dominated; (B) turbid

phytoplankton-dominated.

in relation to macrophyte loss. This evidence prompts a more thorough investigation into the nature of the changes that have occurred to determine if regime shifts are evident or if the sites are merely continuing to respond to a chronic stressor. Further, it prompts an investigation into the spatial and hydro-geomorphic controls on these sites, to examine whether the changes are predictable according to situation. Cursory observations lead to the identification of four possible wetland response types (Reid and Gell, 2011) which attempt to describe and explain patterns of change in billabongs in relation to shifts from macrophytedominated to phytoplankton dominated regimes which are illustrated by the conceptual models in Figure 2 .

These records were synthesized in Gell and Reid (2014) and forms part of the review of wetland change described and discussed below.

\section{Selection and Analysis of Key Records}

This synthesis enabled the identification of the most appropriate sites to be examined to better understand the nature of change. Seventeen records of wetland change were selected from each of the four response types to examine the nature of the response in detail. The response types comprised the upland tributaries which appeared most resistant to change, the mid-basin, deeper wetlands that appeared to have switched permanently, those in the lower reaches that tended to switch condition and a lowland group that showed little consistent pattern of change perhaps owing to local pollution impacts (Figure 3 ). The nature of the selected wetlands is outlined in Table 1.

All but one of these records (Sinclair's Flat) extend well beyond the last two centuries, with several extending more than a 1000 years. Most records therefore, cover the critical pre- to post-European settlement boundary and also provide information on the natural variability of systems. The pre- to post-European boundary used in each record is based on the inferences from the original studies which utilize a range of lines of evidence, including ${ }^{210} \mathrm{~Pb}$ dating profiles, appearance of introduced pollen taxa and peaks in magnetic susceptibility, thought to be associated with early post settlement soil erosion (Reid, 2002; Reid et al., 2007).

Because the principal interest of this research is on changes to the trophic structure of billabongs in relation to pelagic vs. littoral productivity the synthesis compares the relative abundances of preserved diatoms grouped according to habitat preference. The major habitat groups in billabongs are planktonic, epipelic 


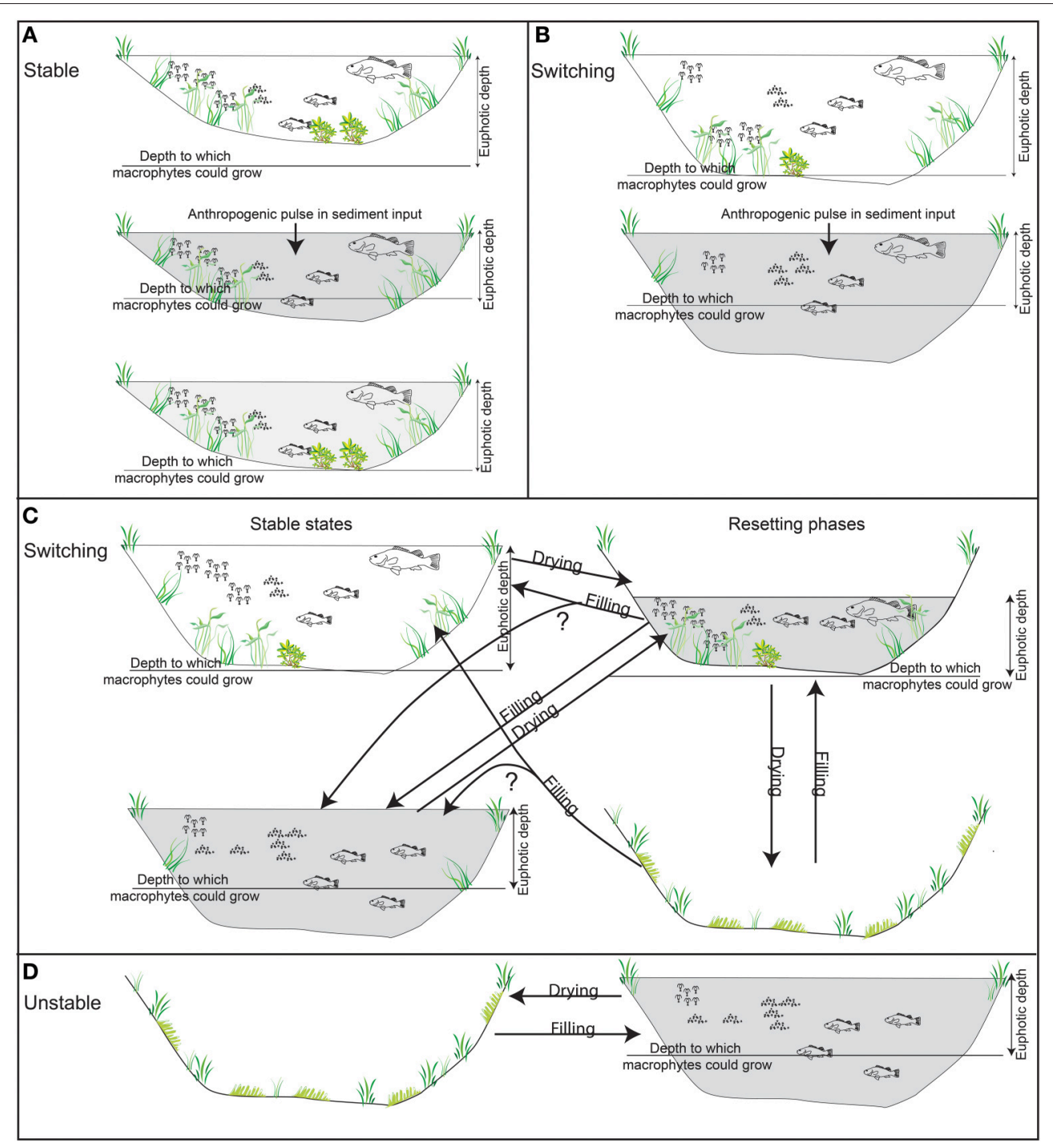

FIGURE 2 | Conceptual models explaining the relationships between billabong geomorphology, hydrology, and the proposed response types. Stable billabongs are resilient to reduced photic depth because pulses in anthropogenic sediment input do not reduce photic depth enough to remove the majority of the bed from the photic zone (A). Switching billabongs are less resilient to reduced photic depth because pulses in sediment input result in the removal of the majority of the bed from the photic zone (B). In both cases, feedback processes may act to strengthen the original or new state once sediment influx is reduced. Switching billabongs may also be reset to either state by drying events (C). Unstable billabongs dry frequently and so fail to develop stable states (D).

(living on mud surfaces), and epiphytic (living attached to plants or other hard surfaces) forms. A further group consists of a suite of genera with poorly defined habitat preferences that are typically associated with variable or frequently disturbed environments (collectively referred to hereafter as "small Fragilaria").

The diatom and dating data then were synthesized for analysis using non-metric multi-dimensional scaling of resemblance matrices based on Bray Curtis Similarity Indices calculated using diatom assemblage (relative abundance of habitat groups) data. This ordination was used to explore patterns in diatom assemblage structure in relation to the abundance of the major habitat groups and change over time in assemblage structure within individual billabong records. Interactions between changes over time in response to European settlement and billabong type were explored by comparing positions of samples on the first axis of the nMDS, the main axis of variation in the data set, in relation to era (pre vs. post) and type (stable, switching, and unstable). Subsets of samples were selected from within individual records for this analysis to reduce the influence of temporal autocorrelation and uncertainty over the timing of the pre- to post-European boundary in the records. Thus, samples were selected to maximize depth gaps between samples and avoid samples immediately above and below the inferred pre- to post-European boundary. The numbers of included and excluded samples for each record and the sample depths for included samples are provided in Table 2. Analyses were conducted in Primer v6 (nMDS). 


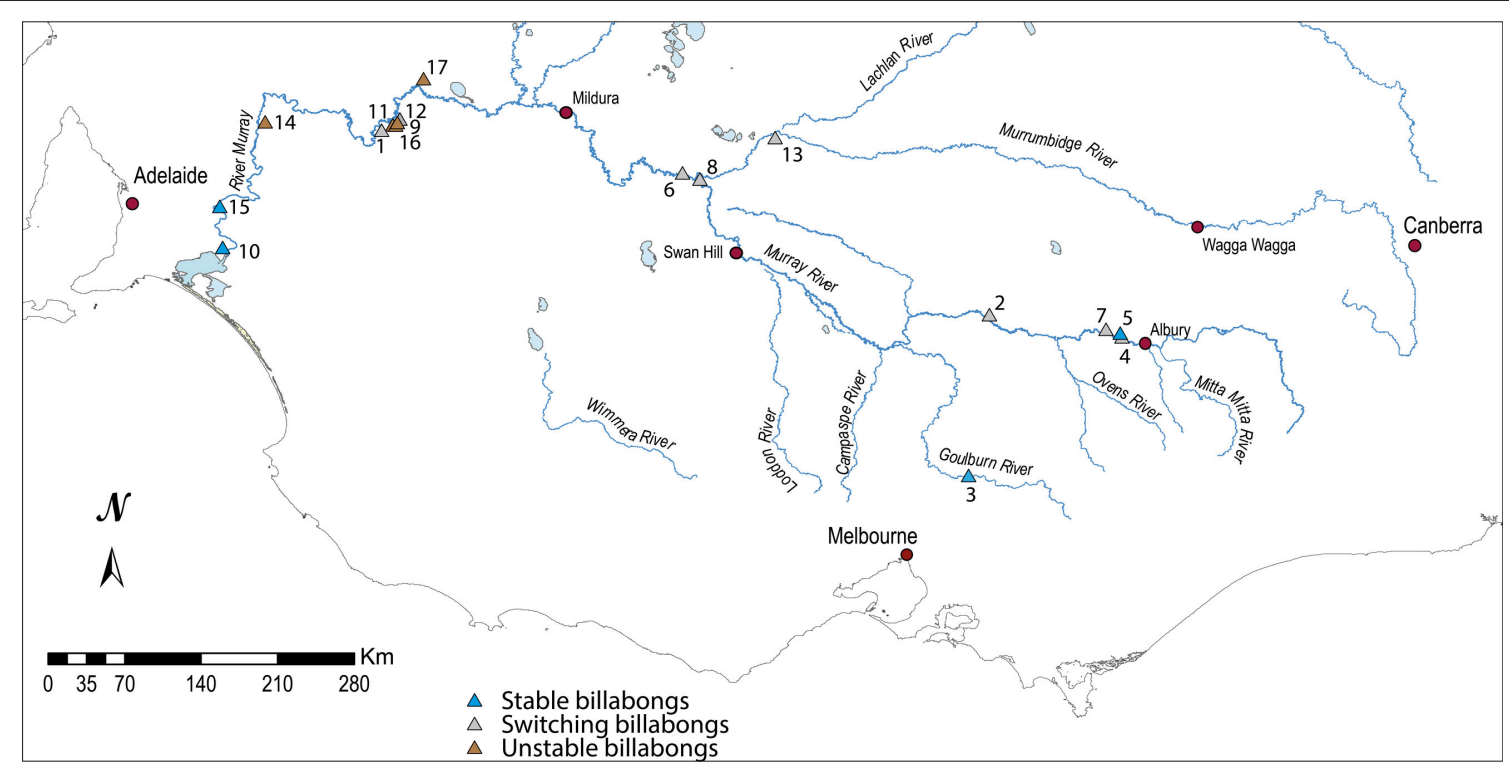

FIGURE 3 | Distribution of the 17 billabongs in the southern Murray Darling Basin classed by response type.

TABLE 1 | Features of the 17 wetlands analyzed.

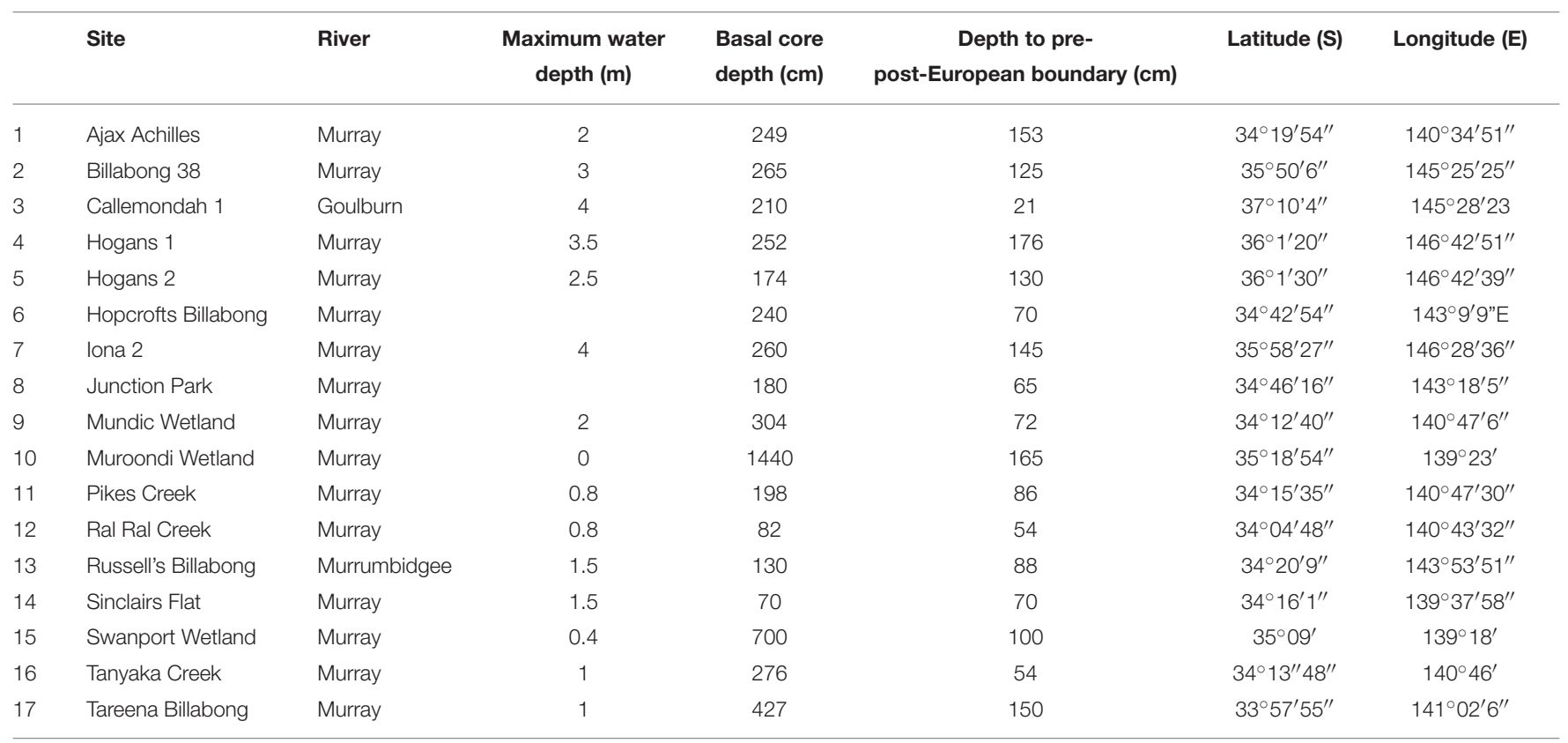

\section{RESULTS}

\section{Synthesis of Species Assemblage Changes}

A synthesis of 51 fossil diatom records from wetlands of the Southern Murray Basin floodplain reveal comprehensive change in condition (Gell and Reid, 2014). Increased sedimentation was observed in $55 \%$ of wetlands raising the threat of complete sedimentation in the more shallow systems (Gell et al., 2013). Most wetlands exhibited a shift to true plankton (Aulacoseira spp.), or a shift to tychoplanktonic (Sayer, 2001) diatom species (Pseudostaurosira brevistriata, Staurosira construens, and varieties, Staurosirella pinnata) competitive in turbid conditions, reflecting an increase in pelagic forms at the expense of epiphytic (Cocconeis placentula, Gomphonema spp.) and littoral (Epithemia spp., Eunotia serpentina) taxa (Sonneman et al., 2000). In particular, large, deep wetlands in the mid-reaches were vulnerable to abrupt shifts to dominance by Aulacoseira spp. due to increasing turbidity impacting on the light environment of an extensive area of the benthos at once (Ogden, 2000; Reid et al., 2007). 
TABLE 2 | Samples included in exploration of interaction between type and era (pre-European vs. Post-European) illustrated in Figure 8.

\begin{tabular}{|c|c|c|c|c|c|c|}
\hline \multirow[t]{2}{*}{ Billabong } & \multicolumn{3}{|c|}{ Post-European samples } & \multicolumn{3}{|c|}{ Pre-European samples } \\
\hline & $\begin{array}{l}\text { No. of samples } \\
\text { not included }\end{array}$ & $\begin{array}{l}\text { No. of samples } \\
\text { included }\end{array}$ & $\begin{array}{l}\text { Depths (in cm) } \\
\text { samples included }\end{array}$ & $\begin{array}{l}\text { No. of samples } \\
\text { not included }\end{array}$ & $\begin{array}{l}\text { No. of samples } \\
\text { included }\end{array}$ & $\begin{array}{c}\text { Depths (in cm) } \\
\text { samples included }\end{array}$ \\
\hline Ajax & 67 & 5 & $0,30,60,121$ & 21 & 4 & $161,181,201,221$ \\
\hline B38 & 5 & 5 & $5,45,85,125,165$ & 1 & 3 & $205,225,245$ \\
\hline C1 & 17 & 5 & $0,4,8,12,16$ & 23 & 5 & $32,52,72,92,112$ \\
\hline $\mathrm{H} 1$ & 32 & 5 & $0,32,64,105,130$ & 16 & 4 & $200,224,248,272$ \\
\hline $\mathrm{H} 2$ & 18 & 5 & $0,16,32,64,96$ & 11 & 2 & 137,164 \\
\hline Hopcrofts & 4 & 4 & $0,20,40,60$ & 12 & 5 & $90,120,150,180,210$ \\
\hline 12 & 20 & 4 & $0,40,80,120$ & 2 & 2 & 160,176 \\
\hline JP & 9 & 3 & $0,20,40$ & 7 & 4 & $90,110,130,160$ \\
\hline Mundic & 56 & 5 & $0,15,30,45,60$ & 66 & 6 & $90,120,152,180,212,272$ \\
\hline Murrundi & 1 & 6 & $25,45,65,85,105,125$ & 51 & 12 & $\begin{array}{c}205,305,405,505,605,705,805 \\
905,1005,1105,1205,1305\end{array}$ \\
\hline Pikes & 40 & 3 & $0,20,60$ & 48 & 4 & $106,126,146,166$ \\
\hline Ral Ral & 90 & 5 & $0.5,10,20,30,40$ & 25 & 4 & $60,66,72,78$ \\
\hline Russell's & 9 & 4 & $0,24,48,96$ & 3 & 1 & 112 \\
\hline Sinclair & 47 & 4 & $0,10,20,30$ & - & - & - \\
\hline Swanport & 5 & 4 & $0,20,40,60$ & 9 & 6 & $120,180,280,400,500,600$ \\
\hline Tanyaka & 15 & 3 & $0,38,48$ & 45 & 5 & $94,144,184,224,264$ \\
\hline Tareena & 18 & 7 & $0,20,40,60,80,100,120$ & 24 & 5 & $200,250,300,350,400$ \\
\hline
\end{tabular}

Lower in the system the diatom flora in the wetlands shifted from species considered competitive in low nutrient systems, owing to their nitrogen-fixing endosymbionts (Epithemiaceae; Stancheva et al., 2013), to taxa widely known to reflect elevated nutrient concentrations (Van Dam et al., 1994). These variously include Cyclostephanos dubius, Cyclotella meneghiniana, Nitzschia spp. (incl. N. amphibia, N. palea), and Stephanodiscus spp. (Sayer, 2001; Bennion et al., 2004). Substantial declines in Epithemia spp. were evident in records from Lake Cullulleraine (Fluin et al., 2010), Loveday Wetland and Loch Luna (Gell et al., 2007), Sinclairs Flat (Grundell et al., 2012), Kings Billabong (Kattel et al., 2014) and upstream at Hogan's Billabong (Reid et al., 2007) while E. serpentina was seen to decline in Loch Luna, Pikes Creek, Ral Ral Creek, and Hopcrofts Lagoon (Gell et al., 2005b). Increases in nutrient indicators, including Stephanodiscus/Cyclostephanos (Sinclairs Flat, Ral Ral Creek, Pikes Creek, Balranald Weir, Loveday Wetland, Coonoocoocabil Lagoon, and the Coorong), C. meneghiniana (Tareena Billabong, Gooragool Lagoon, Bomen Lagoon, Psyche Bend Lagoon, and Berry Jerry Lagoon), and Nitzschia spp. (Loveday Lagoon, Sinclairs Flat, Ral Ral Creek, Loch Luna, and Hogan's Billabong), were widespread. Large scale hydrological change has seen the onset of both dryland and irrigation salinization which is reflected in the arrival of halobiontic taxa, such as Amphora coffeaeformis and A. veneta, Gyrosigma spp., Pleurosigma spp., and Tryblionella spp. (Gasse et al., 1995; Gell, 1997), from early after European settlement (e.g., Gell et al., 2005a, 2007). In effect, these records provide evidence for widespread impact on the floodplain wetlands and identify increased flux of sediments, nutrients and salts as major stressors.

\section{Analysis of 17 Billabong Data Set}

The nMDS ordination of the diatom assemblages of all samples (sediment depths) from all 17 sites selected for detailed analysis, is shown in Figure 4. The position of samples in ordination space reflects the relative abundances of the major habitat groups in each sample, as illustrated by the bubble plots in each of the four panels in Figure 4. These show that samples plotting to the lower left typically have abundant planktonic diatoms (Figure 4A), those to the lower right typically have abundant epiphytic diatoms (Figure 4B) while those plotting to the top have abundant small Fragilaria (Figure 4D). Samples with abundant epipelic diatoms do not cluster strongly in any one area in relation to axes 1 and 2 (Figure 4C). Accordingly nMDS axis 1 reflects variation in the abundance of planktonic (low values) and epiphytic (high values) diatoms in each sample.

The ordination also reveals patterns in the diatom assemblages of billabongs and how these assemblages vary over time (Figure 5). The patterns observed largely affirm the classification of response types from Reid and Gell (2011), although uncertain chronology means that separation of the type II and III billabongs proposed in the Reid and Gell (2011) classification is difficult. The modified classification is described below:

(1) Stable-records are dominated by epiphytic diatoms and samples remain largely within the lower right quadrant of the ordination (e.g., Callemondah 1, Swanport, and Muroondi wetlands in Figure 5);

(2) Switching-records are dominated by epiphytic or planktonic diatoms (i.e., samples plot low on axis 2). The planktonic state predominates in the post-European phase and the most recent samples always contain $>55 \%$ 

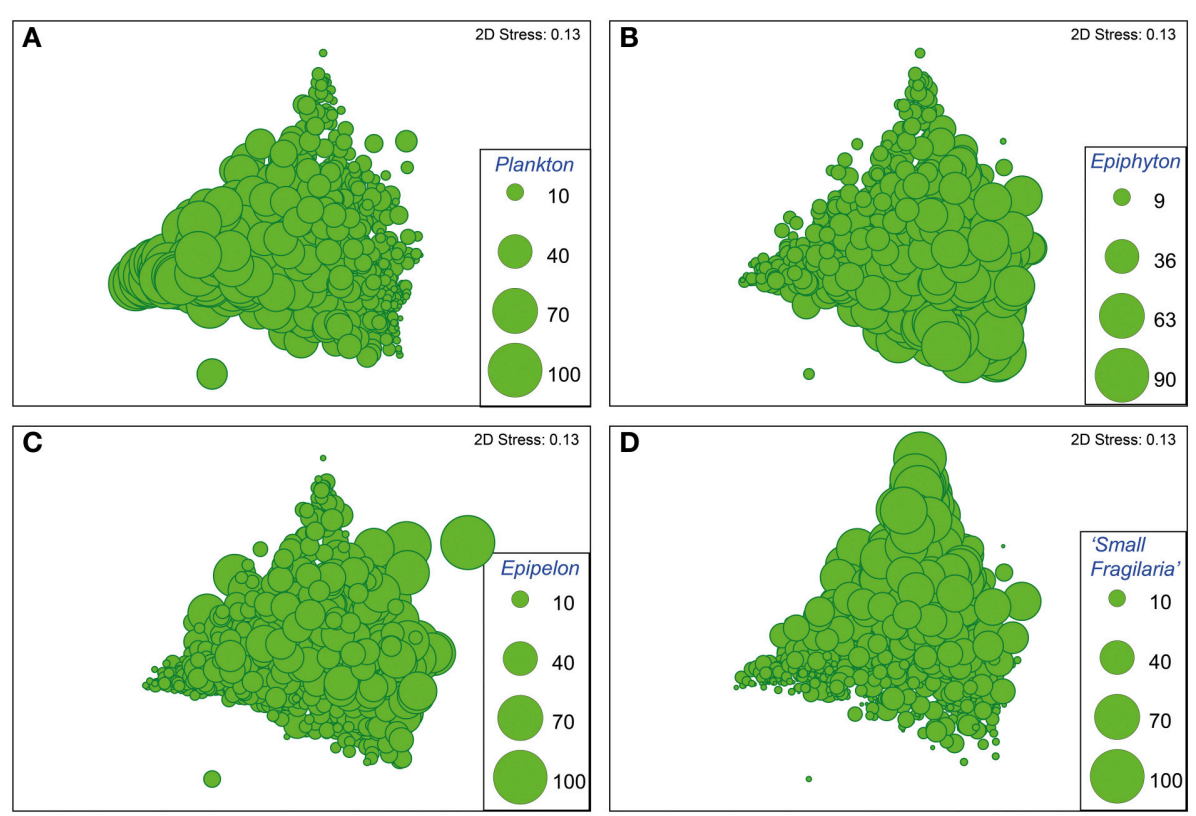

FIGURE 4 | Bubble plots of the full 17-billabong data set (966 samples) on nMDS axes 1 and 2 based on a resemblance matrix of Bray-Curtis similarity measures using relative abundances of diatoms grouped according to preferred habitat (planktonic, epiphytic, epipelic, small Fragilaria). Bubble size indicates the relative abundance of planktonic (A), epiphytic (B), epipelic (C), and small Fragilaria (D) diatoms. 2D stress values indicate the degree that the 2-dimensional ordination represents a distortion of the relationships between samples in the resemblance matrix, with 0 representing perfect representation. Values greater than 0.3 indicate points are close to being arbitrarily placed in the 2 -dimensional ordination, thus the $2 \mathrm{D}$ stress value of 0.14 indicates the ordination is suitable for illustrating general patterns (Clarke and Warwick, 2001).

planktonic diatoms (e.g., Hogans 1, Hopcrofts Billabong, and Billabong 38 in Figure 5). Among switching billabongs, some (e.g., Hopcrofts Billabong in Figure 5) appear to have undergone periods of planktonic dominance prior to European settlement. These billabongs are equivalent to the type III billabongs in Reid and Gell (2011) and may switch via mechanisms illustrated in Figure 2C. However, these are included within the broader switching group here because uncertain chronology means that the possibility that no phases of planktonic dominance occurred in the pre-European period cannot be ruled out;

(3) Unstable-assemblages vary greatly through time and contain relatively high abundances of "small Fragilaria" (e.g., Tareena, Mundic, and Tanyaka wetlands in Figure 5).

Patterns of change over time, within the three response types, are further illustrated by the time series of nMDS axis 1 and 2 scores (Figures 6, 7). These show consistent declines in axis 1 scores from the pre- to post-European periods among switching billabongs. These declines reflect shifts from relatively high abundance of epiphytic diatoms to relatively high abundance of planktonic diatoms. In most cases this decline in axis 1 scores appears to be a step change although the transition is also distinguished by high variability in scores (Figure 6). Declines in axis 1 scores are also apparent in several unstable billabongs (Tareena, Mundic, Tanyaka, and Pikes), however these unstable billabongs are distinguished from the switching billabongs by generally higher and more variable axis 2 scores (Figures 7, 8).
Hogans 2, classed as a stable billabong also shows a clear and abrupt drop in axis 1 scores, however, the drop is not as great as in switching billabongs (around 0 compared with around -1), reflecting the lower proportion of planktonic diatoms in the most recent sediments of Hogans $2(<50 \%)$ compared to the switching billabongs ( $>55 \%)$.

There is also a spatial pattern in the distribution of the aforementioned response types (Figure 3):

- Stable billabongs are found in the upper middle Murray River, the Goulburn River and in the lower Murray River below the Murray gorge. As noted above, Ogden (2000) also found Ovens River billabongs were relatively stable;

- Switching billabongs are found in the mid-Murray River (Hume Dam to Darling confluence) and lower Murrumbidgee River. Within this group, possible phases of pre-European plankton dominance are apparent further downstream (from around the Murrumbidgee-Murray River confluence) but not upstream;

- Unstable billabongs are confined to the Murray River wetlands situated between the Darling River confluence in south-west NSW and the Murray Gorge in South Australia.

It is perhaps noteworthy that the billabongs that fit less clearly within each of the response types tend to be situated within regions dominated by billabongs with other response types. Hogans 2, for example, lies in a region dominated by switching billabongs and Ajax lies in a region with mostly unstable billabongs (Figure 3). 

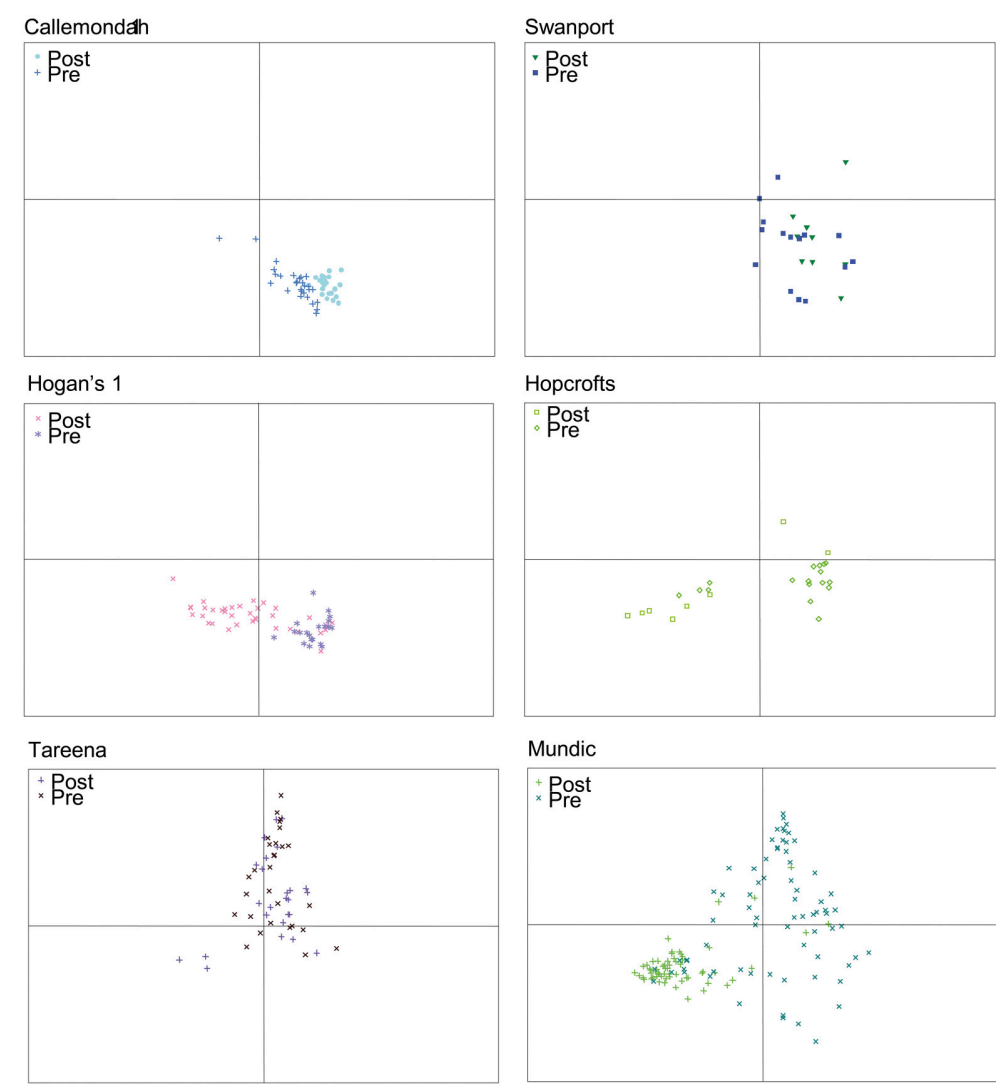

Hopcrofts
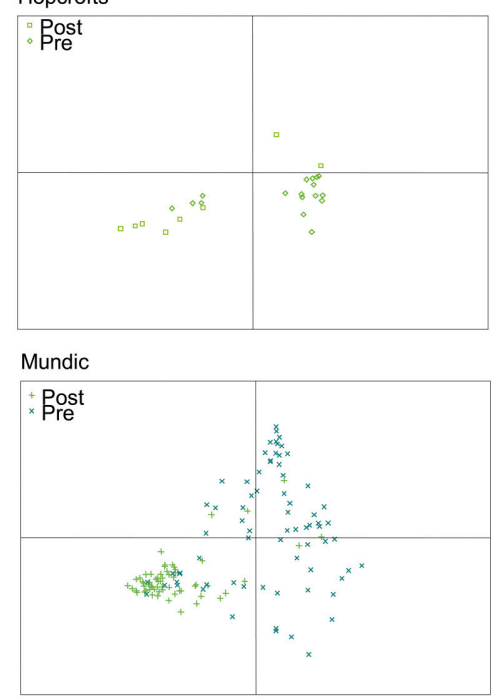

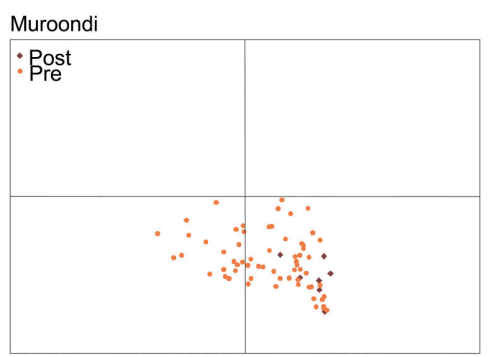

Billabong 38

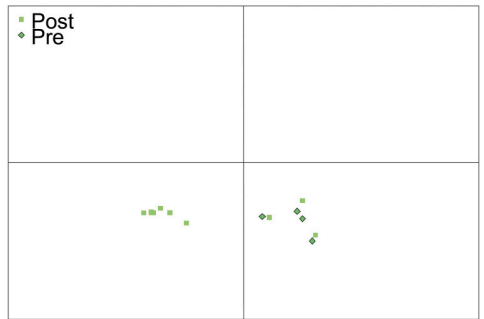

Tanayaka

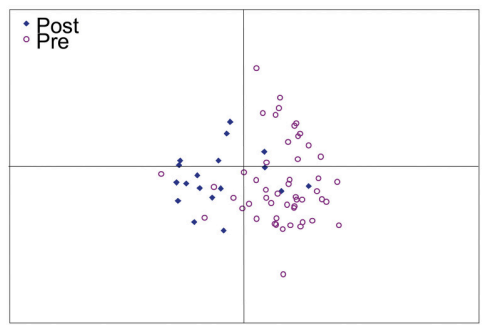

FIGURE 5 | nMDS ordination plots of axes 1 and 2 scores for diatom assemblages from specific billabong sediment records illustrating examples of "stable" (Callemondah 1, Swanport, Muroondi), "switching" (Hogans 1, Hopcrofts, Billabong 38), and "unstable" (Tareena, Tanyaka, Mundic) billabong response types. Samples in each plot are distinguished as being from the pre-European (Pre) and post-European (Post) settlement periods Note that each site plot is a subset of the data points shown in the nMDS ordination of all sites and samples shown in Figure 4.

\section{DISCUSSION}

Given the high level of natural variability inherent in Australian hydroclimatic systems, and the extended return interval of high impact events, it is insufficient to base the management of a natural system on knowledge derived from recent monitoring. Only an extended record of variability and change coupled with contemporary monitoring is able to quantify the magnitude of change from historical, and clearly reveal the nature of that change. Only then can restoration approaches that target the known shifts in condition be applied.

A recent synthesis of diatom-inferred change (Gell and Reid, 2014) across 51 wetlands highlighted drivers, such as high sedimentation rates and elevated turbidity as well as increased concentrations of nutrients and salts, operating widely across the southern Basin. Importantly, the identified responses varied between sites with some wetlands appearing resistant to change and those more sensitive changing abruptly, particularly in relation to macrophyte loss. This evidence prompted a more thorough investigation into the nature of the changes that have occurred to determine if regime shifts are evident or if the sites are merely continuing to respond to a chronic stressor. Further, it prompted an investigation into the spatial and hydro-geomorphic controls on these sites, to examine whether the changes are predictable according to situation. Cursory observations lead to the identification of four possible wetland response types (Reid and Gell, 2011) which attempted to describe and explain patterns of change in billabongs in relation to shifts from macrophyte-dominated to phytoplankton dominated regimes. This detailed analysis of 17 wetlands allowed only for the identification of three clear response types; those resistant or resilient to stressors (stable), those which tend to frequently change and recover (unstable) and those which appear to have changed into a permanent phytoplankton-dominated state (switching). The tendency of a wetland to conform to one or another type appears to be controlled by the hydromorphic setting with those in the upper reaches stable, those in the lower unstable, and those most sensitive to permanent switching in the middle reaches.

\section{The Magnitude of Change}

This recent synthesis of long term records of change from floodplain wetlands across the southern Murray Darling Basin provides evidence of the degree to which wetlands have departed from their long term historical range of variability, and reveals the spatial extent of change across the region. The data presented 


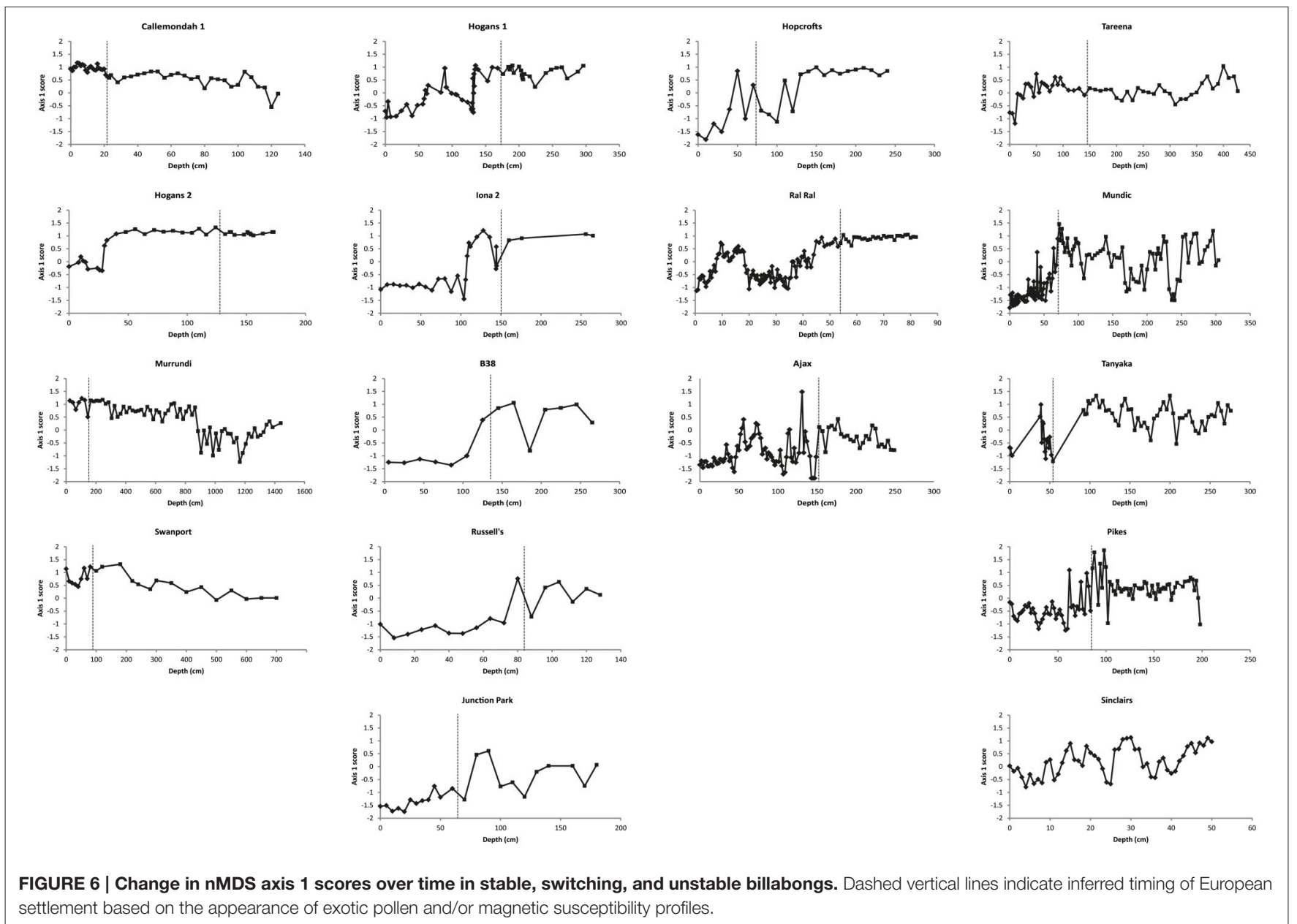

in Gell and Reid (2014), and the detailed analysis presented here, report on records of fossil diatoms that are sensitive to water quality (Reid et al., 1995) and to habitat change (Reid and Ogden, 2009), but are less reflective of broader system health. Also, fossil records are most readily available in more permanent wetlands where sediment accumulation is continuous and so any synthesis may be skewed away from understanding change in seasonal or intermittent sites. The opportunity provided here however, is in the powerful insights that can be gained by monitoring retrospectively into ages beyond the reach of contemporary monitoring approaches, personal recollection and even documents such as diaries and photography.

Contemporary monitoring of waterway condition across the Basin focuses on water quality, fish and waterbird populations and tree health. These data underpin studies that claim the waterways of the basin to be widely degraded (Norris et al., 2002; Davies et al., 2012). Macroinvertebrate monitoring programs rely on comparison of assemblages between test and reference sites. While these approaches are not limited in the sites that may be analyzed, they are greatly limited by the extent of time covered in the data sets and the changing quality of data collection through time. As such, they overlook many decades of change that may have occurred before suitable instrumentation was available and they lack any pre- (European) impact condition for context and assessment of the natural amplitude of variability. Further, it is widely acknowledged that the condition of lowland waterways have changed and few, if any, unimpacted reference sites remain. Monitoring programs that assess impact relative to a "less modified" reference site will inevitably underestimate the magnitude of change that has occurred through time.

An assessment based on a synthesis of long term change from 51 wetlands is a substantial sample by which to assess basin wide change. It represents the largest synthesis of paleolimnological records across any floodplain and so provides the strongest available record of wetland condition change. This record reveals the impact of industrial development on the condition of wetlands across the southern Murray Darling Basin has been comprehensive and greater than the impact of millennial scale climate change.

\section{The Nature of the Change}

The combined syntheses of wetland change reveals widespread increased sedimentation rates and the replacement of epiphytic and littoral taxa with planktonic and facultative planktonic forms, particularly in the vulnerable large, deep wetlands of the middle reaches. This is strong evidence for the widespread 


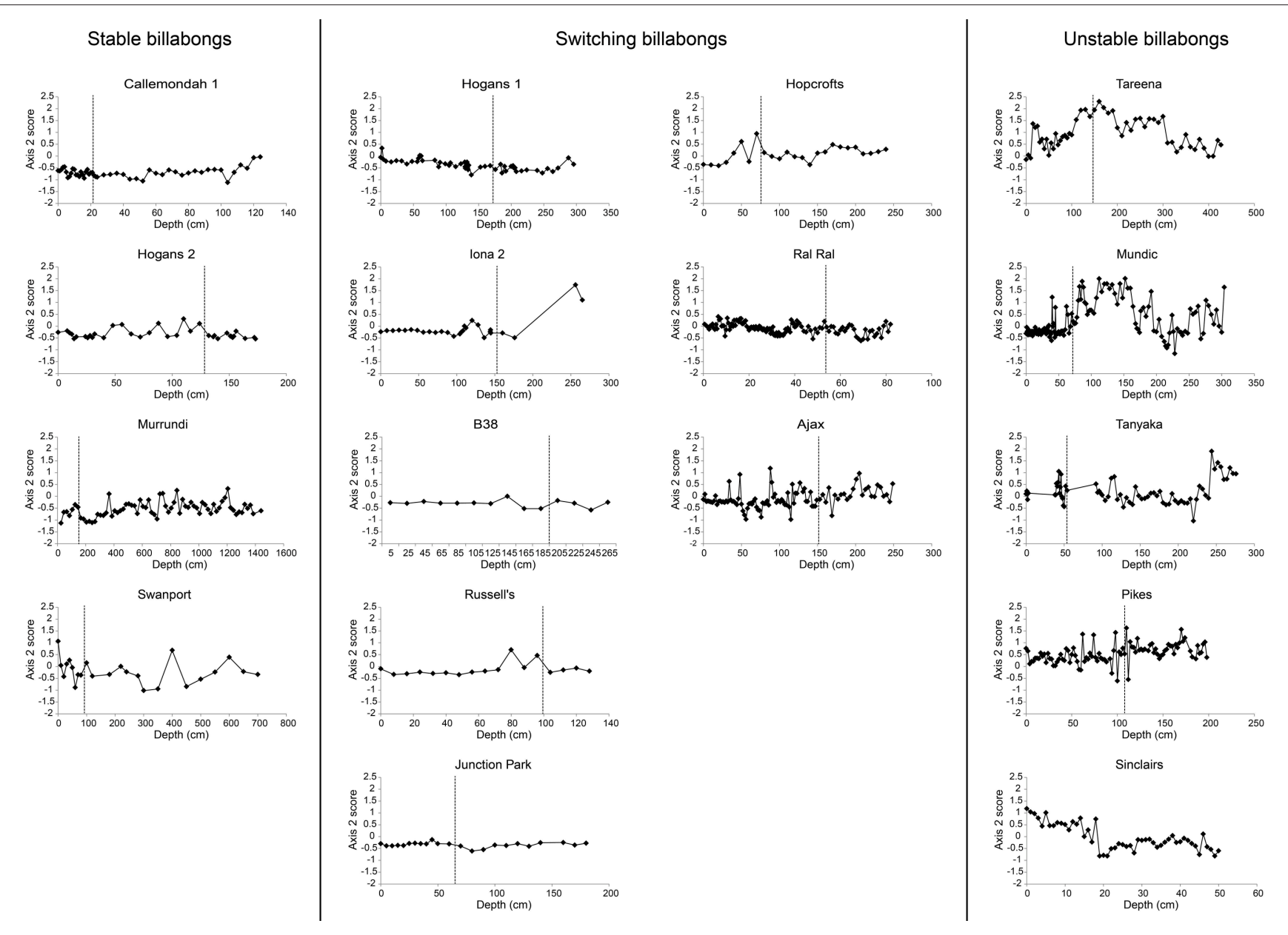

FIGURE 7 | Change in nMDS axis 2 scores over time in stable, switching, and unstable billabongs. Dashed vertical lines indicate inferred timing of European settlement based on the appearance of exotic pollen and/or magnetic susceptibility profiles.

increase in flux of fine sediments from the floodplain or channel banks into rivers and then to wetlands. To date the mix in the source of these sediments remains largely unknown with evidence for subsoil (Olley and Wallbrink, 2004) sources and catchment erosion more broadly (Reid et al., 2007) posited. While government agencies have acted to mitigate this flux through soil conservation measures and the national "Landcare" program, sedimentation rates appear to be increasing despite the likely sediment trapping effect of dams and weirs. It remains that the ongoing flux of sediment is advantaging those diatom taxa that can gain light from within the water body rather than attached to surfaces.

There is widespread increase in key nutrient indicator taxa in many records suggesting the widespread increase in nutrient flux, despite water quality monitoring data showing no particular trend over recent decades. Coincident with the rise of eutraphentic diatom taxa is the widespread decline in the relative abundance of species within the Epithemiaceae. Their decline is evidence in wetland records from Mildura (Kings Billabong; Kattel et al., 2014) to Blanchetown (Sinclairs Flat; Grundell et al., 2012). These forms are known to host nitrogen-fixing endosymbionts and so are competitive in low nitrate waters (Stancheva et al., 2013). While this relationship has not been explored in detail in an Australian context, the widespread decline in Epithemia spp. in floodplain records is supporting evidence for a weakening of their competitive advantage after industrial development.

The longer sediment records that extend beyond the arrival of European settlers attest to the natural, elevated levels of salinity relative to many other provinces of the world. The evidence of high numbers of Gyrosigma spp. and Tryblionella spp. from 3500 years ago in Tareena Billabong (Gell et al., 2005a) is clear evidence of phases of elevated salinity during drier climates. Even so, it is clear that floodplain wetland salinity has increased widely since European settlement even in wetlands considered to be in good ecological condition today (Gell et al., 2007). Several wetlands, including those permanently filled with river water, attest to unprecedented salinity in recent times where modern water quality monitoring reveal no clear change in river salinity. The salinization of many intermittent wetlands that are without long term records of change are clearly evident from the death of fringing aquatic plants and riparian trees (Figure 9). 

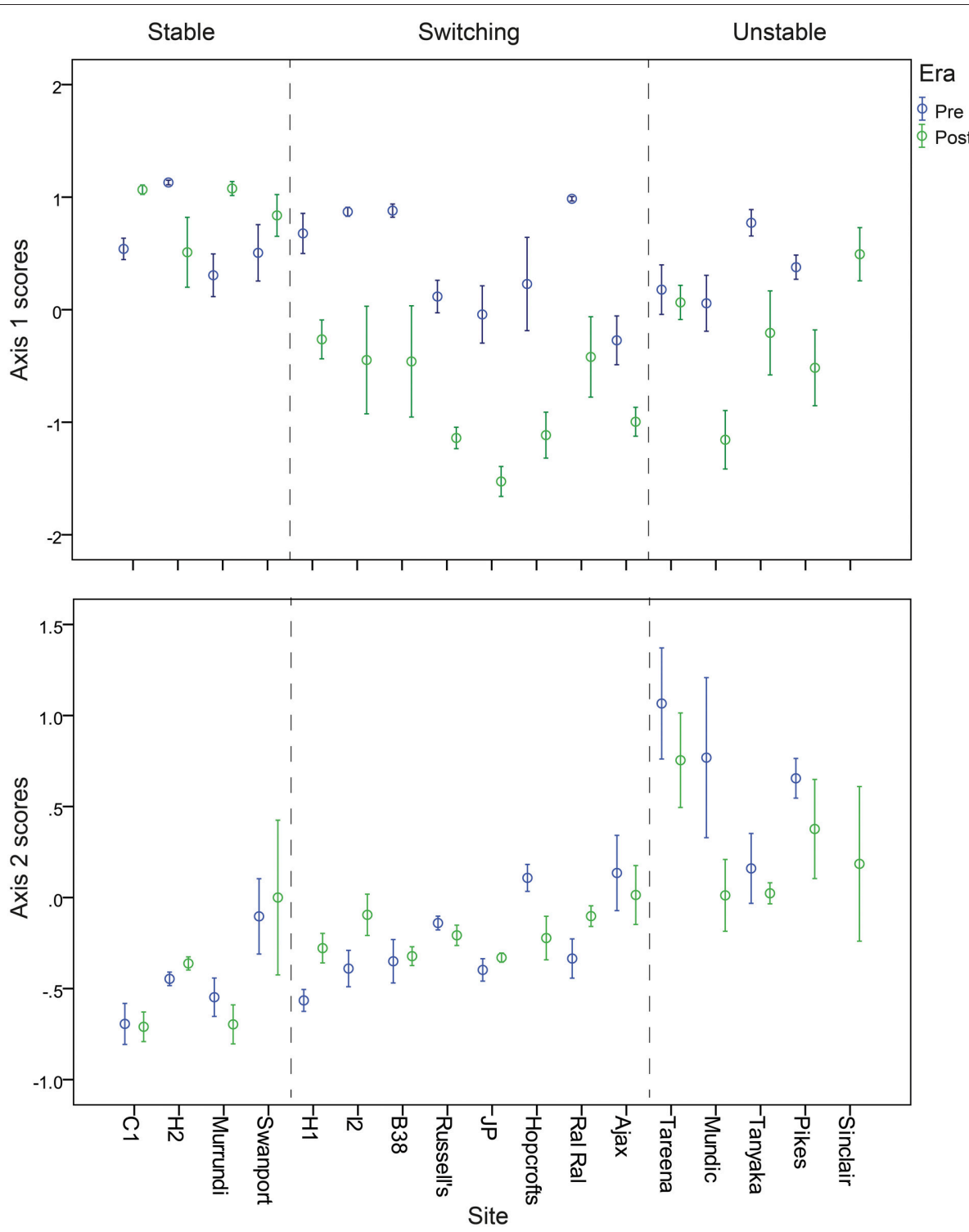

FIGURE 8 | Mean nMDS axis 1 (top) and axis 2 (bottom) scores for subsets of billabong sediment samples from pre- and post-European sediments arranged by billabong and billabong response type.

Shallow lakes, such as floodplain wetlands, have long been identified as systems at risk of non-linear change. These lakes are considered susceptible to regime shifts where increasing loads of nutrients or fine sediments impact on the light environment, limiting the depth to which light energy can penetrate. Under low or moderate nutrient and fine sediment loading, tight nutrient cycling, stabilization of surface sediments and allelopathic effects limit the release of nutrients and sediments into the waterbody, maintaining water clarity and advantaging rooted plants able to access sediment nutrients (Scheffer et al., 1993; Scheffer and Carpenter, 2003). However, with increases in nutrients and/or sediments these stabilizing forces may be overcome leading to declining water clarity and declining macrophyte abundance. The decline in macrophytes allows for the release of nutrients and sediments from the benthos reinforcing a shift to a phytoplankton-dominated state. While monitoring records that demonstrate regime shifts complete with shifts in stabilizing forces remain few (Capon et al., 2015), in the Murray Darling Basin it is possible that regime shifts occurred before the inception if monitoring programs. So, evidence for regime shifts may be limited to long term records of change that are only available using paleolimnological approaches.

Ogden (2000) was the first to invoke regime shifts as a possible mechanism to interpret the decline in fossil chydorid (cladocera) assemblages, and their replacement by pelagic bosminids, in floodplain wetlands in the upper Murray. This evidence has been reinforced by evidence for the rise of river plankton at the expense of epiphytic and benthic diatoms (Reid et al., 2007). This 


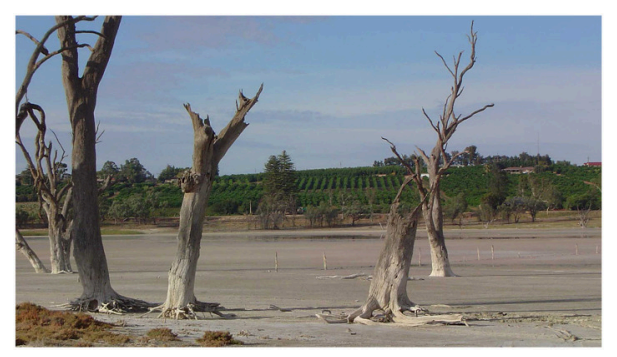

FIGURE 9 | The recent salinization of Ramco Lagoon in South Australia is clear owing to the presence of dead River Red Gum (Eucalyptus camaldulensis) and fringing sedge (Cyperus sp.). The irrigation of crops on soils overlying Miocene limestone has driven an increased salt flux to the wetland.

detailed analysis of the diatom assemblages from 17 floodplain wetlands has revealed that many sites across the system spanning more than 1000 river kilometers have shifted to assemblages dominated by euplanktonic and/or tychoplanktonic forms from early in European settlement. Critically, some wetlands also tend to resist this change and yet others exhibit no apparent stability. This analysis classifies wetlands according to their response typology, reveals the distribution of particular response types and interprets the causes of change:

Stable: Resistant or resilient wetlands exist mostly in the upper tributaries that host shallow wetlands that are stable owing to their limited vulnerability to reduced photic depth;

Switching: wetlands that have undergone change from macrophyte dominance to phytoplankton dominance. This is due to their vulnerability to reduced photic depth being large and deep in the middle reaches of the main floodplain. Among these wetlands some do show evidence of regime shifts prior to European settlement. A spatial pattern in the location of apparent repeat switching suggests that variable water levels and perhaps even complete drying, may trigger switches;

Unstable: Variable wetlands in the lower catchment that have been impacted by multiple stressors.

This typology suggests that many wetlands have undergone regime shifts, but that these shifts were often early in European settlement and beyond the instrumental record. The pattern of change reinforces this interpretation in that it is the hydromorphic situation that mediates the individual wetland's response, on account of its vulnerability to a changed light environment. The widespread existence of state switching, albeit with the possibility of resetting in intermittent sites, attests to the basin wide increase in sediment and nutrient flux. While the source of these sediments remains unclear, evidence of elevated accumulation rates of fine sediments near inlets to wetlands (Grundell et al., 2012) suggest that the channel itself is a likely vehicle transferring fine sediment from the catchment to riparian lakes.

\section{Restoration Approaches}

The management of the waterways of the Murray Darling Basin has been a national priority for more than a century.
Heightened concern for declining condition have culminated in the formulation of the Murray Darling Basin Plan (MDBA, 2013). The principal tenet of the plan is that the natural ecosystem has suffered from the over-allocation of river waters to industrial and domestic use, particularly the use of water to drive a highly productive irrigation industry. The principal mechanism proposed to restore the Basin's waterways is the return of 3200 GL/yr of environmental flows. The benefit of this allocation is being monitored in programs focussing on, but not restricted to, fish populations, waterbirds and macroinvertebrates. Given the 2005 "cap on allocations," and the institution of a water market to direct water allocation, the main mechanism left to government to secure water for flows are buy-backs of user entitlements or the mitigation of evaporative losses through expensive infrastructure. Governments sensitive to the political pressure of disaffected irrigation communities are likely to find the infrustructure approach appealing (Wittwer and Dixon, 2013).

Contemporary monitoring programs based on changes in waterbird and fish population and riparian tree condition have little historical context and so changes are rarely attributed to the stressors that emerged before river regulation. They are also elements of the ecosystem that respond particularly to the availability of water. It follows then that when understanding of a system is derived from these elements recent changes in condition are prominent and restoration programs are focussed on short time solutions based on water volume. From such a short term view it is likely that any understanding of the impacts of abstraction and regulation and the focus of management is on water volume, wetting and drying regimes and river flow. This focus is further emphasized by the historical focus of monitoring on rivers, rather than wetlands, reinforcing the restoration effort to be on river flow rather than wetland condition.

Long term sediment-based records of change overcome the limitations of this approach by providing evidence for the antecedent conditions of wetlands. It is also capable of demonstrating the mechanisms of change allowing for a focus on drivers other than flow. The risk to management of the focus on flow is not only the opportunity costs of the reallocation, but that the waters remain a source of the principal cause of wetland change. So, paleolimnological approaches reveal a greater challenge for management and one which is possibly less palatable owing to the complexity of the drivers of change involved. However, with a longer term perspective we come to understand better the "leakiness" of catchments, the abrupt or gradual nature of change, the present condition in the light of the long term and shifting levels of variability and wetland ontogeny which is largely overlooked under a short term focus.

The contemporary focus on the return of environmental flows and river wetland connectivity invokes a single cause of changethe alteration of hydrological systems. Paleolimnological evidence has documented increased fluxes in elements such as nutrients, salts, and sediment particles and seeks to also manage for these fluxes in concert with water provision. Also, it remains that change may occur through the excedence of some threshold, either due to changing hydrological or water quality drivers. Management then needs to consider non-linear change to fully understand the causal mechanisms. Lastly, 
wetlands accrete sediments and the basins which hold water become shallower which influences the hydrogeomorphology and light environment. In one site a return to diverse aquatic beds is celebrated as a management outcome when it is in fact an ontogenetic change owing to rapid transformation to a shallow wetland owing to accelerated sedimentation (Gell et al., 2005b). Management by way of water provision, in the absence of investment in managing other drivers, risks the commitment of considerable resources for little, or temporary benefit.

If the pre-impact food web is unknown, then it is not possible to convincingly attest to a restored system. This can only be declared after reference to the paleo-community derived from the archived indicators. If a functional ecosystem is returned, but one that is structurally different, or based on different species, to that in the past, then the site is effectively rehabilitated but different. This circumstance, demonstrable with the evidence of the past, will encourage management to explore the nature of target setting and the expectations of the community to environmental restoration programs. It also will raise awareness of sediment load as an impediment to restoration by watering and so reveal the true complexity of the management challenge. Further in the eFlows debate it will reveal the desire to both allocate flows, and to mitigate sediment and nutrient flux, and so reveal the true ecological benefit, against the costs and sacrifices, of reallocating water. Further it will challenge the focus on water volumes and flow to allow for the implementation of a mix of restorative measures to ensure the biggest ecological bounce from the trade in water. Even despite this declining flows under a warming climate will ensure that even well balanced restoration programs will continue to face great challenges into the future.

\section{CONCLUSION}

Programs dedicated to the management of the freshwater ecosystems of the Murray Darling Basin in Australia have evolved into adversarial contests over the allocation of scarce volumes of water that will diminish under climate change (Jones et al., 2002 b). The recent plan to recover large volumes of water used for irrigation to restore these ecosystems has been underpinned by monitoring and research programs that have largely spanned recent decades only. These approaches have identified river flow and water allocation as the principal means of restoring the natural systems.

A synthesis and detailed analysis of an array of paleolimnological records of change in the southern basin have revealed that considerable wetland change occurred after European settlement, but well before contemporary monitoring programs commenced. These attest to other, substantial drivers of change and demote water volume as only one of many natural resource management issues. This approach reveals that elevated flux of nutrients and sediments are key drivers of change and that wetlands have exhibited complex response mechanisms attributable to their hydromorphic context. Further, river water is identified as a possible vehicle transporting the sediments and nutrients to the wetlands. These records have also extended the temporal realm of ecological knowledge into the period where more sensitive wetlands may be expected to have responded to early industrialization. In effect, the records do reveal early and abrupt responses and that, in many cases, these conditions have persisted. It stands that reinforcement mechanisms are now in place that may resist restoration attempts.

These studies attest to the ecological and political risk of the ongoing focus on volume as the principal means of securing the restoration of wetland systems. While the quality of river water is compromised the risk remains that the significant investment in water volume under the Basin Plan both alienates the irrigation industry and creates little ecological recovery. Such an outcome threatens the regional community's commitment to the restoration cause given the considerable opportunity cost they have been required to meet through reduced water allocations.

A perspective that incorporates the evidence of ecosystem change drawn from sediment-based studies, in association with contemporary monitoring approaches, would better identify the broader spectrum of drivers of change and direct management to implement a better targeted mix of management measures. This would direct the restoration effort to be as much about the mitigation of nutrient and sediment flux as the withdrawal of valuable water from private entitlements. The funds released from the reduced level of water buy-back can be dedicated to more targeted intervention measures such as riparian watering, nutrient trapping, and bank stabilization. Such an approach would share the load of resource re-allocation, reinstate the commitment of local communities and increase the sustainability of the Plan.

\section{AUTHOR CONTRIBUTIONS}

PG drafted the manuscript. MR provided Figures 1-7 and described the analysis of the 17 test sites. Both authors have undertaken or supervised the analysis of the diatoms records analyzed.

\section{ACKNOWLEDGMENTS}

This synthesis relies on the records of change produced by many colleagues and students. The work of Kate Adamson, Jennie Fluin, Rosie Grundell, Ifteara Khanum, Sorell Lock, Ralph Ogden, Martin Thoms, and Brendan Walsh is greatly appreciated. The original studies were supported by Australian Research Council Linkage grants (LP0560552 and LP0667819) to PG and several grants through the Australian Institute for Nuclear Science and Engineering. Further support was provided by the River Murray Catchment Water Management Board. The authors appreciate the comments from two anonymous reviewers. 


\section{REFERENCES}

Barr, C., Tibby, J., Gell, P., Tyler, J., Zawadzki, A., and Jacobsen, G. (2014). Climatic variability in southeastern Australia over the last 1500 years inferred from the fossil diatom records of two crater lakes. Quat. Sci. Rev. 95, 115-131. doi: 10.1016/j.quascirev.2014.05.001

Battarbee, R. W., Jones, V. J., Flower, R. J., Cameron, N. G., Bennion, H., Carvalho, L., et al. (2001). "Diatoms," in Tracking Environmental Change Using Lake Sediments. Volume 3: Terrestrial, Algal, and Siliceous Indicators, eds J. P. Smol, H. J. B. Birks, and W. M. Last (Dordrecht: Kluwer), 155-202.

Bennion, H., Fluin, J., and Simpson, G. L. (2004). Assessing eutrophication and reference conditions for Scottish freshwater lochs using subfossil diatoms. J. Appl. Ecol. 41, 124-138. doi: 10.1111/j.1365-2664.2004. 00874.x

Bradshaw, E. G., Nielsen, A. B., and Anderson, N. J. (2005). Mid- to lateHolocene land-use change and lake development at Dallund Sø, Denmark: synthesis of multiproxy data, linking land and lake. Holocene 15, 1152-1162. doi: 10.1191/0959683605hl887rp

Bradshaw, E. G., Nielsen, A. B., and Anderson, N. J. (2006). Using diatoms to assess the impacts of prehistoric, pre-industrial, and modern land-use on Danish lakes. Reg. Environ. Change 6, 17-24. doi: 10.1007/s10113-0050007-4

Capon, S. J., Lynch, A. J. J., Bond, N., Chessman, B. C., Davis, J., Davidson, N., et al. (2015). Regime shifts, thresholds and multiple stable states in freshwater ecosystems; a critical appraisal of the evidence. Sci. Total Environ. 534, 122-130. doi: 10.1016/j.scitotenv.2015.02.045

Chessman, B., Bate, N., Gell, P. A., and Newall, P. (2007). A diatom species index for bioassessment of Australian rivers. Mar. Freshw. Res. 58, 542-557. doi: 10.1071/MF06220

Clarke, K. R., and Warwick, R. M. (2001). Change in Marine Communities: An Approach to Statistical Analysis and Interpretation, 2nd Edn. Plymouth: National Environment Research Council.

Davidson, T. A., Reid, M. A., Sayer, C. D., and Chilcott, S. (2013). Palaeolimnological records of shallow-lake biodiversity change: exploring the merits of single versus multi-proxy approaches. J. Paleolimnol. 49, 431-446. doi: 10.1007/s10933-013-9696-8

Davies, P. E., Stewardson, M. J., Hillman, T. J., Roberts, J. R., and Thoms, M. C. (2012). Sustainable Rivers Audit 2: The Ecological Health of Rivers in the Murray-Darling Basin at the End of the Millennium Drought (2008-2010) Summary. Canberra: Murray Darling Basin Authority.

Davis, J., Sim, L., and Chambers, J. (2010). Multiple stressors and regime shifts in shallow aquatic ecosystems in antipodean landscapes. Freshw. Biol. 55, 5-18. doi: 10.1111/j.1365-2427.2009.02376.x

Dearing, J. A., Acma, B., Bub, S., Chambers, F. M., Chen, X., Cooper, J., et al. (2015). Socio-ecological systems in the Anthropocene: the need for integrating social and biophysical records at regional scales. Anthropocene Rev. 2, 220-246. doi: $10.1177 / 2053019615579128$

Fluin, J., Tibby, J., and Gell, P. (2010). Testing the efficacy of electrical conductivity (EC) reconstructions from the lower Murray River (SE Australia): a comparison between measured and inferred EC. J. Paleolimnol. 43, 309-322. doi: $10.1007 /$ s10933-009-9333-8

Fritz, S. C. (1999). Twentieth-century salinity and water-level fluctuations in Devils Lake, North Dakota: test of a diatom-based transfer function. Limnol. Oceanogr. 35, 1771-1781. doi: 10.4319/lo.1990.35.8.1771

Fritz, S. C., Juggins, S., Battarbee, R. W., and Engstrom, D. R. (1991). Reconstruction of past changes in salinity and climate using a diatom-based transfer function Nature 352, 706-708.

Gasse, F., Juggins, S., and Ben Khelifa, L. (1995). Diatom-based transfer functions for inferring hydrochemical characteristics of African palaeolakes. Palaeogeogr. Palaleocol. 117, 31-54. doi: 10.1016/0031-0182(94)00122-O

Gell, P., Baldwin, D., Little, F., Tibby, J., and Hancock, G. (2007). The impact of regulation and salinisation on floodplain lakes: the lower River Murray, Australia. Hydrobiologia 591, 135-146. doi: 10.1007/s10750-007-0806-3

Gell, P., Bulpin, S., Wallbrink, P., Bickford, S., and Hancock, G. (2005a). Tareena Billabong - a palaeolimnological history of an everchanging wetland, Chowilla Floodplain, lower Murray-Darling Basin. Mar. Freshw. Res. 56, 441-456. doi: 10.1071/MF04107
Gell, P., and Little, F. (2006). Water Quality History of Murrumbidgee River Floodplain Wetlands. Wagga Wagga: Murrumbidgee Catchment Management Authority.

Gell, P., Mills, K., and Grundell, R. (2013). The legacy of climate and catchment change: the real challenge for wetland management. Hydrobiologia 708, 133-144. doi: 10.1007/s10750-012-1163-4

Gell, P., and Reid, M. (2014). Assessing change in floodplain wetland condition in the Murray Darling Basin. Anthropocene 8, 39-45. doi: 10.1016/j.ancene.2014.12.002

Gell, P., Tibby, J., Fluin, J., Leahy, P., Reid, M., Adamson, K., et al. (2005b). Accessing limnological change and variability using fossil diatom assemblages, south-east Australia. River Res. Appl. 21, 257-269. doi: 10.1002/rra.845

Gell, P. A. (1997). The development of a diatom data base for inferring lake salinity: towards a quantitative approach for reconstructing past climates. Aust. J. Bot. 45, 389-423. doi: 10.1071/BT96036

Gell, P. A., Sluiter, I. R., and Fluin, J. (2002). Seasonal and inter-annual variations in diatom assemblages in Murray River-connected wetlands in northwest Victoria, Australia. Mar. Freshw. Res. 53, 981-992. doi: 10.1071/MF01021

Giguet-Covex, C., Pansu, J., Arnaud, F., Rey, P.-J., Griggo, C., Gielly, L., et al. (2014). Long livestock farming history and human landscape shaping revealed by lake sediment DNA. Nat. Commun. 5:3211. doi: 10.1038/ncomms4211

Grundell, R., Gell, P., Zawadzki, A., and Mills, K. (2012). Interaction between a river and its wetland: evidence from spatial variability in diatom and radioisotope records. J. Paleolimnol. 47, 205-219. doi: 10.1007/s10933-0119572-3

Jones, G., Hillman, T., Kingsford, R., MacMahon, T., Walker, K., Arthington, A., et al. (2002a). Independent Report of the Expert Reference Panel on Environmental Flows and Water Quality Requirements for the River Murray System. Canberra: Collaborative Research Centre for Freshwater Ecology.

Jones, R. N., Bowler, J. M., and McMahon, T. A. (1998). A high resolution Holocene record of $\mathrm{P} / \mathrm{E}$ ratio from closed lakes in Western Victoria. Palaeoclimates 3, 51-82.

Jones, R. N., Whetton, P. H., Walsh, K. J. E., and Page, C. M. (2002b). Future Impacts of Climate Variability, Climate Change and Land Use Change on Water Resources in the Murray Darling Basin: Overview and Draft Program of Research. Canberra: Murray Darling Basin Commission.

Kattel, G., Gell, P., Grundell, R., Weller, S., Perga, M., Zawadzki, A., et al. (2014). Tracking a century of change in trophic structure from a floodplain wetland: integrating evidence of fossil diatom and herbivore assemblages and sedimentary and chitinous $\delta 13 \mathrm{C}$. Freshw. Biol. 60, 711-723. doi: $10.1111 /$ fwb. 12521

Krammer, K., and Lange-Bertalot, H. (1986). Susswasserflora von Mitteleuropa. Bacillariophyceae, Teil i: Naviculaceae. Stuttgart: Gustav Fischer Verlag.

Krammer, K., and Lange-Bertalot, H. (1988). Susswasserflora von Mitteleuropa. Bacillariophyceae Teil ii: Bacillariaceae, Epithemiaceae, Surirellaceae. Stuttgart: Gustav Fischer Verlag.

Krammer, K., and Lange-Bertalot, H. (1991a). Susswasserflora von Mitteleuropa. Bacillariophyceae Teil iii: Centrales, Fragilariaceae, Eunotiaceae. Stuttgart: Gustav Fischer Verlag.

Krammer, K., and Lange-Bertalot, H. (1991b). Susswasserflora von Mitteleuropa. Bacillariophyceae Teil iv: Achnanthaceae. Stuttgart: Gustav Fischer Verlag.

Laurance, W. F., Dell, B., Turton, S. M., Lawes, M. J., Hutley, L. B., McCallum, H., et al. (2011). The 10 Australian ecosystems most vulnerable to tipping points. Biol. Conserv. 144, 1472-1480. doi: 10.1016/j.biocon.2011.01.016

Maheshwari, B. L., Walker, K. F., and MacMahon, T. A. (1995). Effects of regulation on the flow regime of the River Murray, Australia. Regul. River 10, 15-38. doi: 10.1002/rrr.3450100103

Marsland, K., and Nicol, J. (2007). 2006 River Murray Wetlands Baseline Survey. Vegetation Component. Adelaide: South Australian Research and Development Institute.

MDBA (2013). MDBA Basin Plan. Canberra: Murray Darling Basin Authority.

Norris, R. H., Liston, P., Davies, N., Coysh, J., Dyer, F., Linke, S., et al. (2002). Snapshot of the Murray-Darling Basin River Condition. Canberra: Cooperative Research Centre for Freshwater Ecology.

Ogden, R. W. (2000). Modern and historical variation in aquatic macrophyte cover of billabongs associated with catchment development. Regul. River 16, 497-512. doi: 10.1002/1099-1646(200009/10)16:5 < 497::AID-RRR600>3.0.CO;2-Y 
Olley, J., and Wallbrink, P. (2004). Recent Trends in Turbidity and Suspended Sediment Loads in the Murrumbidgee River, NSW, Australia. Wallingford, CT: IAHS Publication.

Philibert, A., Gell, P., Newall, P., Chessman, B., and Bate, N. (2006). Development of diatom-based tools for assessing stream water quality in south eastern Australia: assessment of environmental transfer functions. Hydrobiologia 572, 103-114. doi: 10.1007/s10750-006-0371-1

Pittock, J., and Finlayson, C. M. (2011). Australia's Murray-Darling Basin: freshwater ecosystem conservation options in an era of climate change. Mar. Freshw. Res. 62, 232-243. doi: 10.1071/MF09319

Prosser, I. P., Rutherfurd, I. D., Olley, J. M., Young, W. J., Wallbrink, P. J., and Moran, C. J. (2001). Large-scale patterns of erosion and sediment transport in river networks, with examples from Australia. Mar Freshw. Res. 52, 81-99. doi: 10.1071/MF00033

Reid, M., and Gell, P. (2011). Regional wetland response typology, Murray-Darling Basin, Australia. PAGES News 19, 62-64.

Reid, M. A. (2002). "A diatom-based palaeoecological study of two billabongs on the Goulburn River floodplain, southeast Australia," in Proceedings of the15th International Diatom Symposium, ed J. John (Ruggell: Gantner Verlag), 237-253.

Reid, M. A., and Ogden, R. W. (2006). Trend, variability or extreme event? The importance of long-term perspectives in river ecology. River Res. Appl. 22, 167-177. doi: 10.1002/rra.903

Reid, M. A., and Ogden, R. W. (2009). Factors affecting diatom distribution in floodplain lakes of the southeast Murray Basin, Australia and implications for palaeolimnological studies. J. Paleolimnol. 41, 453-470. doi: 10.1007/s10933008-9236-0

Reid, M. A., Sayer, C. D., Kershaw, A. P., and Heijnis, H. (2007). Palaeolimnological evidence for submerged plant loss in a floodplain lake associated with accelerated catchment soil erosion (Murray River, Australia). J. Paleolimnol. 38, 191-208. doi: 10.1007/s10933-006-9067-9

Reid, M. A., Tibby, J., Penny, D., and Gell, P. (1995). The use of diatoms to assess past and present water quality. Aust. J. Ecol. 20, 57-64. doi: 10.1111/j.14429993.1995.tb00522.x

Sayer, C. D. (2001). Problems with the application of diatom-total phosphorous transfer functions - examples from a shallow English lake. Freshw. Biol. 46, 743-757. doi: 10.1046/j.1365-2427.2001.00714.x

Sayer, C. D., Burgess, A., Katerina, K., Davidson, T. A., Peglar, S., Yang, H., et al. (2010). Long-term dynamics of submerged macrophytes and algae in a small and shallow, eutrophic lake: implications for the stability of macrophytedominance. Freshw. Biol. 55, 565-583. doi: 10.1111/j.1365-2427.2009.02353.x

Scheffer, M., and Carpenter, S. R. (2003). Catastrophic regime shifts in ecosystems: linking theory to observation. Trends Ecol. Evol. 18, 648-656. doi: 10.1016/j.tree.2003.09.002

Scheffer, M., Hosper, S. H., Meijer, M. L., and Moss, B. (1993). Alternative equilibria in shallow lakes. Trends Ecol. Evol. 8, 275-279. doi: 10.1016/01695347(93)90254-M

Silva, P. (2014). Psyche Bend Lagoon: from a Productive Wetland to an Acidifed Wasteland within a Century. Unpublished honours thesis, Ballarat: Federation University Australia.
Sonneman, J., Sincock, A., Fluin, J., Reid, M., Newall, P., Tibby, J., et al. (2000). An Illustrated Guide to Common Stream Diatom Species from Temperate Australia. Albury: The Murray-Darling Freshwater Research Centre.

Stancheva, R., Sheath, R. G., Read, B. A., McArthur, K. D., Schroepfer, C., Kociolek, J. P., et al. (2013). Nitrogen-fixing cyanobacteria (freeliving and diatom endosymbionts): their use in southern California stream bioassessment. Hydrobiologia 720, 111-127. doi: 10.1007/s10750-0131630-6

Tibby, J., Gell, P. A., Fluin, J., and Sluiter, I. R. K. (2007b). Diatom-salinity relationships in wetlands: assessing the influence of salinity variability and site effects, with particular reference to the development of inference models. Hydrobiologia 591, 207-218. doi: 10.1007/s10750-007-0803-6

Tibby, J., Lane, M., and Gell, P. A. (2007a). Local knowledge as a basis for environmental management: a cautionary tale from Lake Ainsworth, northern New South Wales. Environ. Conserv. 34, 334-341. doi $10.1017 /$ S037689290700433X

Tibby, J., and Reid, M. A. (2004). A model for inferring past conductivity in low salinity waters derived from Murray River (Australia) diatom plankton. Mar Freshw. Res 55, 597-607. doi: 10.1071/MF04032

Tibby, J., Reid, M. A., Fluin, J., Hart, B. T., and Kershaw, A. P. (2003). Assessing long-term $\mathrm{pH}$ change in an Australian river catchment using monitoring and palaeolimnological data. Environ. Sci. Technol. 37, 3250-3255. doi: $10.1021 /$ es0263644

Van Dam, H., Mertens, A., and Sinkeldam, J. (1994). A coded checklist and ecological indicator values of freshwater diatoms from the Netherlands. Aquat. Ecol. 28, 117-133. doi: 10.1007/BF02334251

Walker, K. F., and Thoms, M. C. (1993). Environmental-effects of flow regulation on the lower River Murray, Australia. Regul. Rivers Res. Manage. 8, 103-119. doi: 10.1002/rrr.3450080114

Wang, R., Dearing, J. A., Langdon, P. G., Zhang, E., Yang, X., Dakos, V., et al. (2012). Flickering gives early warning signals of a critical transition to a eutrophic lake state. Nature 492, 419-422. doi: 10.1038/nature11655

Warner, R. F. (1987). The impacts of alternating flood- and drought-dominated regimes on channel morphology at Penrith, New South Wales, Australia. IAHS Publication 68, 327-338.

Wittwer, D., and Dixon, J. (2013). Effective use of public funding in the Murray-Darling Basin: a comparison of buy-backs and infrastructure upgrades. Aust. J. Agric. Resour. Econ. 57, 399-421. doi: 10.1111/1467-8489. 12001

Conflict of Interest Statement: The authors declare that the research was conducted in the absence of any commercial or financial relationships that could be construed as a potential conflict of interest.

Copyright (C) 2016 Gell and Reid. This is an open-access article distributed under the terms of the Creative Commons Attribution License (CC BY). The use, distribution or reproduction in other forums is permitted, provided the original author(s) or licensor are credited and that the original publication in this journal is cited, in accordance with accepted academic practice. No use, distribution or reproduction is permitted which does not comply with these terms 